\title{
A Review of Zebra Mussel Biology, Distribution, Aquatic Ecosystem Impacts, and Control with Specific Emphasis on South Dakota, USA
}

\author{
Brandon Vanderbush ${ }^{1}$, Chris Longhenry', David 0. Lucchesi ${ }^{2}$, Michael E. Barnes ${ }^{3}$ (i) \\ ${ }^{1}$ South Dakota Department of Game, Fish and Parks, Chamberlain, South Dakota, USA \\ ${ }^{2}$ South Dakota Department of Game, Fish and Parks, Sioux Falls, South Dakota, USA \\ ${ }^{3}$ South Dakota Department of Game, Fish and Parks, McNenny State Fish Hatchery, Spearfish, South Dakota, USA \\ Email: brandon.vanderbush@state.sd.us, chris.longhenry@state.sd.us, dave.lucchesi@state.sd.us, mike.barnes@state.sd.us
}

How to cite this paper: Vanderbush, B. Longhenry, C., Lucchesi, D.O. and Barnes, M.E. (2021) A Review of Zebra Mussel Biology, Distribution, Aquatic Ecosystem Impacts, and Control with Specific Emphasis on South Dakota, USA. Open Journal of Ecology, 11, 163-182.

https://doi.org/10.4236/oje.2021.112014

Received: January 14, 2021

Accepted: February 19, 2021

Published: February 22, 2021

Copyright $\odot 2021$ by author(s) and Scientific Research Publishing Inc. This work is licensed under the Creative Commons Attribution International License (CC BY 4.0).

http://creativecommons.org/licenses/by/4.0/

\begin{abstract}
Zebra mussels Dreissena polymorpha are a native bivalve from eastern Europe. They were first detected in North America in Lake St. Clair in 1988 and were presumably introduced via infested ballast water. Zebra mussels have spread rapidly across the United States, with 31 states reporting infestations as of 2019. Zebra mussels were first detected in South Dakota, USA, in 2015 in Lewis and Clark Lake and McCook Lake, with subsequent infestations occurring in Lake Yankton in 2017, Lakes Francis Case and Sharpe in 2019, and Pickerel Lake, Kampeska Lake, and Lake Cochrane in 2020. This review paper presents information on zebra mussel biology and control, with specific information on the waters of South Dakota, USA.
\end{abstract}

\section{Keywords}

Zebra Mussel, Dreissena polymorpha, South Dakota, North America

\section{Introduction}

The zebra mussel Dreissena polymorpha is a bivalve native to eastern Europe [1] [2]. It is a small, brown, freshwater mussel with a cream-colored zebra stripe pattern that varies among individuals [2]. It inhabits large freshwater lakes and rivers [3] but has also been found in a wide variety of aquatic habitats, including flooded quarries, cooling ponds, and golf course ponds [4]. Zebra mussels exhibit high fecundity [1] [5] [6] and an ability to attach to a variety of surfaces [7] [8] [9] [10] that has allowed them to spread quickly and colonize new locations. Sphaeriidae, Margaritiferidae and Unionidae are the only families of freshwa- 
ter mussels native to North America, with Unionidae being the most common [11]. Zebra mussels belong to the Dreissenidae [11], a mussel family possessing characteristics not found in native mussels. Dreissenid mussels have planktonic larvae that do not require a host to develop. In contrast, native mussels must rely on host species to complete development. In addition, zebra mussels are epifaunal, using byssal threads to attach to hard surfaces and substrates not available to native mussels, which are infaunal and typically bury themselves in sediments [11]. Zebra mussels can attach directly to native North American mussels, which frequently leads to native mussel mortality [11].

Infestation of zebra mussels into new waterbodies is generally believed to occur during early life stages [12] [13] because of external fertilization of eggs in the water column [14] [15] and free-swimming larvae [12] [16]. Both eggs and larvae are capable of movement by either natural or anthropogenic means [17] [18] [19].

Spawning of sexually mature zebra mussels begins when water temperatures reach $12^{\circ} \mathrm{C}$ [5] [6] [12] [20] with optimal spawning temperatures near $18^{\circ} \mathrm{C}$ [20]. Spawning continues as long as temperatures are adequate, even into early fall [21]. A single female zebra mussel releases 30,000 to 40,000 eggs per spawning event [1] [5] [6]. Within a year, one female can produce and release over a million eggs [1] [5]. Several days after fertilization, free swimming larvae emerge and disperse throughout a waterbody [16].

Larval zebra mussels undergo multiple stages of development, with corresponding shifts in behavior. Shortly after hatching, larvae, called veligers, develop velum, an organ used for feeding and movement [15]. Within the first seven days post-hatching, veligers also develop an unornate D-shaped shell followed by a more ornate shell a few days later [15]. After shell formation, organs, including a foot and gill filaments, develop in the mantle cavity [15]. While gill filaments will not become fully developed until later life stages, the foot is fully developed at the veliger stage and can be used either for swimming near or crawling along the bottom [15]. At 16 to 88 days post-hatch, veligers begin to swim or crawl along the bottom in order to find suitable surfaces upon which to settle [15].

Although veligers can settle upon a variety of surfaces, survival is influenced by surface selection. Suitable surfaces are generally hard structures [7] [8] [9] [10], including both natural surfaces such as rocks [7] [8] [9] and artificial surfaces such as cement, steel, or rope [7] [9] [22]. Veligers will also settle upon macrophytes [8] [15] [23] [24], as well as on other invertebrates [8] [25]. Veligers often have difficulty locating suitable substrate for settling, with mortality rates as high as $98 \%$ [26]. After initial settlement, zebra mussels can relocate to more suitable locations [10].

Once initial settlement has occurred, veligers secrete byssal threads to attach to the selected substrate [27] and undergo further development. The velum is replaced by fully functioning gill filaments and a mouth, and the foot moves to a new position and increases in size [15]. These developments facilitate the excre- 
tion and formation of the adult shell [15]. However, even after the development of the adult shell, zebra mussel juveniles are not classified as adults until sexually maturity [15] [28]. In North America, sexually maturity typically occurs at a length of approximately $8 \mathrm{~mm}$, which frequently happens after just one year of growth [6] [21] [25]. Mature mussels commonly congregate into colonies called druses, which are often located in shaded areas [29]. All sizes of zebra mussels exhibit negative phototaxis and prefer darker locations [10] [29] such as crevices, corners and edges [30] [31]. The zebra mussel lifespan is typically between two and nine years [6] [21] [25] [32].

Although generally considered nonmobile, if conditions become unfavorable, zebra mussels can detach their byssal threads and use their feet to seek more suitable habitat [33], particularly rough-textured structures [10]. Juvenile zebra mussels also have special floating byssal threads allowing them to resuspend into the water column and drift to new locations [34]. Toomey et al. [29] found that smaller mussels $(5-10 \mathrm{~mm}$ ) tend to move a greater distance (e.g. $284 \mathrm{~mm}$ ) than larger mussels. Specifically, over a two-hour period, mussels at a length of 5 to 10 $\mathrm{mm}$ mussels move $284 \mathrm{~mm}$, compared to mussels at a length of 10 to $20 \mathrm{~mm}$ that moved $115 \mathrm{~mm}$, and those longer than $20 \mathrm{~mm}$ that moved $47 \mathrm{~mm}$ [29]. While hypoxic conditions will stimulate movement [10], unfavorable calcium levels and water temperature will not [29].

The presence of conspecifics reduces zebra mussel movement [35], leading to their aggregation druses [10]. The formation of druses likely is influenced by the availability of preferred substrates and a predator-avoidance mechanism [10]. However, druses have the potential to reduce mussel growth and condition due to the accumulation of wastes and the depletion of dissolved oxygen and food supplies [36] [37]. If deteriorating conditions in the druse do occur, smaller mussels exit the druse upward, while larger mussels frequently remain stationary and die [36] [37] [38].

Zebra mussel survival and growth is greatly influenced by water temperature. McMahon [20], Cohen [39], and Pollux et al. [13] indicate zebra mussel survival in temperatures ranging from $1{ }^{\circ} \mathrm{C}$ to $30^{\circ} \mathrm{C}$, while Spidle et al. [40] determined that they could survive at somewhat higher temperatures in North America. Although zebra mussels can survive, and grow, for short periods at temperatures greater than $30^{\circ} \mathrm{C}$ [20] [40] [41], they cannot survive at temperatures less than $0^{\circ} \mathrm{C}$ [13] [20] [39] [40] [41]. Growth generally occurs between $6^{\circ} \mathrm{C}$ and $30^{\circ} \mathrm{C}$ [42], with optimal temperatures for growth ranging from $10^{\circ} \mathrm{C}$ to $15^{\circ} \mathrm{C}$ [43]. Zebra mussels located in relatively deep water tend to grow slower, most likely due to lower water temperature and reduced food availability [44].

In addition to temperature requirements, adequate calcium levels are also critical for zebra mussel survival and growth. Minimum calcium concentrations in the range of 12 to $15 \mathrm{mg} / \mathrm{L}$ are required for proper shell development and growth [20] [39] [45] [46] [47]. Low calcium levels can hinder egg development, as well as interfere with muscular contraction, nerve function, cellular cohesion, $\mathrm{pH}$ balance, and other aspects of mussel physiology [13] [47] [48]. Mussel cal- 
cium uptake is influenced by $\mathrm{pH}$ [47] with a desirable range from 6.5 to 9.5 [42].

Zebra mussels are considered intolerant of low dissolved oxygen [49], requiring minimum values of 4 to $6 \mathrm{mg} / \mathrm{L}$ depending on other environmental conditions [42]. As such, the hypolimnion of lakes, impoundments, river floodplains, or other areas with water containing low dissolved oxygen may not be suitable habitat for zebra mussels [44] [50]. Other environmental factors that impact zebra mussel growth and mortality include suspended solids, turbidity, and salinity. High suspended solid concentrations and turbidity can hinder zebra mussel growth by negatively affecting ingestion and clearance rates [51]. Zebra mussels can tolerate salinity ranging from 0.6 to $12 \mathrm{mg} / \mathrm{L}$ [37] [52] [53] with upper lethal limits dependent on temperature [42] [53]. Environmental factors can affect zebra mussel growth and mortality both by acting independently and in combination with each other [44] [46] [47] [50].

Zebra mussels feed primarily on algae, but also consume micro-invertebrates, bacteria, detritus and other organic matter [12]. Food items are obtained by clearing (filter feeding) particles ranging in size from 0.5 to $1200 \mu \mathrm{m}$ into the mantle of the mussel [54] [55]. The preferred size for food items ranges from 15 - $40 \mu \mathrm{m}$ [56]. Clearance rates are affected by mussel size [57] and temperature, with the most advantageous rates occurring at temperatures between $14^{\circ} \mathrm{C}$ and $26^{\circ} \mathrm{C}$ [54]. Clearance rates and food ingestion are also negatively affected by high levels of suspended solids and turbidity, with clearance rates most notably affected when concentrations of suspended solids are greater than $1 \mathrm{mg} / \mathrm{L}$ [51]. In addition to the effects on clearance rates, increased suspended solids can also increase the production of pseudofeces, which are mucous-coated particles expelled from the siphon or mantle [51] [57] [58]. Pseudofeces production does result in increased respiration and energy costs however [51].

\section{Distribution and Spread}

Zebra mussels are native to eastern Europe, originally occupying areas around the Volga River and the Aral, Black, and Caspian Seas [2]. Canal construction during the 1800s facilitated their spread throughout western Europe [1] [2] [19]. Zebra mussels were first reported in North America in 1988 from Lake St. Clair, Michigan [59], likely having been introduced via ballast water [17] [59] [60]. Within a month they were detected in the western basin of Lake Erie [61] and have subsequently spread across much of North America. In 1991, zebra mussels were detected at several locations along the Mississippi River [19] [62] and later were found in the river all the way from Minnesota to Louisiana [19]. Zebra mussels are now found in 31 states [63].

The Missouri River, the longest tributary of the Mississippi, bisects the state of South Dakota and also forms part of the border between South Dakota and Nebraska. Zebra mussels were first detected in the Missouri River near Sioux City, Iowa in 1999 [19] [63]. Zebra mussels were first observed in South Dakota waters in 2015 in Lewis and Clark Lake, which is the furthest downstream Missouri River mainstem reservoir [63]. In the same year, adult zebra mussels were also 
found in McCook Lake, a small lake near North Sioux City, South Dakota maintained by pumping water from the Missouri River [63]. In 2017, zebra mussels were detected in Lake Yankton, South Dakota, a manmade lake located adjacent to the Missouri River, just below Lewis and Clark Lake [64]. Further zebra mussel infestations were not detected again in South Dakota waters until 2019 when adult mussels were found in Lake Francis Case and Lake Sharpe, two Missouri River reservoirs immediately upriver from Lewis and Clark Lake [63]. In 2020, zebra mussel infestations were observed in Pickerel Lake, Lake Kampeska, and Cochrane Lake, all of which are located in Eastern South Dakota at distances in excess of $250 \mathrm{~km}$ from the Missouri River and its reservoirs. Most of the waters in South Dakota have the water chemistry and other environmental characteristics suitable for zebra mussels.

Although barge traffic is believed to have facilitated the transportation of zebra mussels upriver in many river systems [18] [19], it is likely not responsible for mussel introductions into South Dakota waters. Only the lower $1,181 \mathrm{~km}$ of river (Sioux City to the confluence with the Mississippi River), is maintained for navigation and the Missouri River dams upstream from Sioux City lack locks for watercraft passage. However, barges may have indirectly facilitated zebra mussel introduction into South Dakota by transporting them upriver to Sioux City, Iowa, where that population may have served as a source population for introduction by overland transport to Lewis and Clark Lake or Lake Yankton. However, it is more likely that water vessels used for recreation, research, or industrial work such as construction or bridge maintenance, were responsible for introduction [18] [65] [66]. Both zebra mussel adults and veligers have the potential to be transported overland under the right conditions [17] [67] [68] [69]. Adult mussels can attach to boat hulls, motors, and anchors [18] [65] [66], as well as macrophytes attached to trailers or boats [66]. Under cool, moist conditions, attached adult mussels can survive out of water for four days [17] [67] [68] [69]. Veligers can be transported via standing water in boat bilges, motors, and live wells [18] [65] [66]. The most plausible explanation for the spread of zebra mussels in South Dakota is via overland transport by fishing and recreational boats [18] [66].

While wild animals such as ducks, turtles, fish, and other organisms have the potential to transport zebra mussels, [18] [70], waterfowl are the most likely animals to contribute to mussel spread [18] [70]. Although little research has been conducted, it has been hypothesized that veligers and juvenile mussels could become trapped within feathers or debris carried on the feathers or feet of birds [18] [70] [71].

Even though zebra mussels can survive transportation, a single introduction may not be adequate to establish a population [72]. Even in favorable environmental conditions, multiple introductions may be needed to establish a self-sustaining population [13] [20] [39] [40] [42] [53] [65] [72] [73]. Thus, waterbodies that are the closest to existing mussel populations and those most frequented by recreational users are most susceptible to zebra mussel colonization [74]. In addition, fre- 
quently used waterbodies containing zebra mussels can act as reservoirs facilitating zebra mussel spread [65].

\section{Impacts on Aquatic Ecosystems}

The impact of zebra mussels on aquatic ecosystems in North America has varied from a dramatic change in trophic state [75]-[81] to virtually no effect at all [76] [82] [83] [84]. The ability of zebra mussels to increase water clarity is well-documented [61] [76] [79] [85] [86], however some studies have found little to no change in water clarity after introduction [83]. In two Ohio lakes, water clarity increased by $2 \mathrm{~m}$ after zebra mussel introduction [79] [86], while an even greater water clarity increase was observed in the eastern basin of Lake Erie [83]. However, the western and central basins of Lake Erie did not experience a similar water clarity increase [83]. Turbidity in the Detroit River decreased by about 33\% after zebra mussel introductions [76], while water clarity in the Hudson River only increased by 7\% [76]. In general, holomictic lakes and slow-flowing rivers with little water mixing may likely experience a larger increase in water clarity after the introduction of zebra mussels than meromictic lakes or fast-flowing, highly mixed rivers [76].

Zebra mussel impacts on phytoplankton have also varied. The mussels have reduced chlorophyll $a$ in a wide variety of water bodies [81] [87] [88] [89] [90] [91], with a 41\% reduction observed in a small lake in Ireland [81]. However, not all zebra mussel introductions have reduced phytoplankton abundance [84] [92] [93]. Phytoplankton communities may change because of zebra mussels. De Stasio et al. [84] reported a change in the phytoplankton community in Green Bay, Lake Michigan, from chlorophytes to cyanobacteria and diatoms. Increased cyanobacteria densities after zebra mussel introduction are not uncommon [76] [89] [94] [95] [96] [97]. The presence of zebra mussels may be favorable for blooms of the cyanobacteria Microcystis aeruginosa [94] [95], which they find unpalatable due to the presence of hepatotoxins or microcystins [93] [98]. Although zebra mussels can alter the phytoplankton community, overall biomass may stay the same [84].

Zebra mussels may affect zooplankton, both directly through consumption and indirectly through competition for food [78]. Selective consumption appears to be the primary mechanism contributing to changes in zooplankton species composition [77] [78] [99] and abundance [100] [101] [102]. Pace et al. [77] reported that after zebra mussel introduction, zooplankton biomass in the Hudson River decreased over 70\%. After mussel introduction into Lake St. Clair, cladoceran and copepod abundance decreased by $50 \%$, while rotifers declined by over $80 \%$ [102]. However, in Oneida Lake, New York, there was no decrease in Daphnia spp. biomass, but only a shift to larger bodied species [88]. The relatively weaker swimming strength of smaller zooplankton may make them more susceptible to zebra mussel predation [78] [88] [100]. It is also possible that any impacts of zebra mussels on zooplankton may be isolated to only those areas of a 
lake suitable for zebra mussels. There is also a potential that with larger waterbodies, impacts of zebra mussels on zooplankton can be patchy, isolated to areas of a lake with suitable zebra mussel habitat [88] [103].

Most mussel families native to North America have been negatively affected by the introduction of zebra mussels [3] [75]. These impacts can occur by zebra mussels settling on native mussels or by the creation of toxic conditions because of zebra mussel waste, but food competition is likely the primary mechanism behind the decline of native mussels after zebra mussel introductions [3] [75]. The decline in native mussel populations with the expansion of zebra mussels across North America is a major concern to natural resource managers [3] [11] [75].

Zebra mussel introductions have a positive effect on many aquatic invertebrate populations. The appearance of zebra mussel druses often coincides with an increase in the abundance of most invertebrates, such as amphipods, chironomids, oligochaetes, hydrozoans, and smaller mollusks [80] [104]-[110]. Large mollusks, large net-spinning caddisfly, and those invertebrates that use soft substrates may be negatively impacted by zebra mussels [105] [110]. Macro-invertebrates likely benefit from zebra mussels by increasing the availability of food and hard structure. Improved water clarity makes food more accessible [61] [76] [79] [85] [86], and macro-invertebrate food may increase due to increased organic matter resulting from zebra mussel filter feeding [111] [112] [113]. However, most studies attribute increased hard structure due to zebra mussels as the primary reason for increased macro-invertebrate numbers [80] [104] [106] [109] [113] [114] [115]. Druses, with living mussels, dead shells, and bysaal threads, increase bottom complexity, providing protection to invertebrates from predators [109] [110]. In addition, a druse on soft sediment provides the hard surface required by many invertebrates [106] [116].

Evidence of zebra mussel impacts on fish populations is limited. In Lake Erie, walleye Sander vitreus, white bass Morone chrysops, yellow perch Perca flavescens, freshwater drum Aplodinotus grunniens, emerald shiner Notropis hudsonius, and trout-perch Percopsis omiscomaycus populations did not change after zebra mussel introduction [117] [118]. However, gizzard shad Dorosoma cepedianum abundance may have been affected [117]. A decrease in walleye of 50\% to $70 \%$ in Lake St. Clair was observed after the introduction of zebra mussels [82], although this may or may not be a cause-and-effect relationship. The decrease may have been due to mussel-induced water quality decreasing the lower light and higher turbidity conditions more conducive to walleye foraging success [119] [120]. However, increased water clarity and the subsequent increase in aquatic macrophytes [79] [121] benefits other fish species such as muskellunge Esox masquinongy, yellow perch, smallmouth bass Micropterus dolomieu, and other centrarchids [82].

Zebra mussel veligers and adults are consumed by a number of fish species [122] [123]. Predation on veligers has been reported for alewife Alosa pseudo- 
harengus, rainbow smelt Osmerus mordax, gizzard shad, blueback herring Alosa aestivalis, and white perch Morone americana [122] [124]. Adult mussels are commonly consumed by freshwater drum, blue catfish Ictalurus furcatus, redear sunfish Lepomis microlophus, pumpkinseed Lepomis gibbosus, round goby Neogobius melanostomus, and several other fish species [122] [123] [125] [126] [127] [128] [129].

Indirectly, zebra mussels appear to increase yellow perch growth by increasing invertebrate abundance [130]. Although yellow perch and bluegill Lepomis macrochirus foraging success may decrease with the presence of druses [108] [131], any such decrease is more than compensated by the large increase in invertebrate numbers.

Walleye spawning success in Lake Erie was not impacted by zebra mussels [61] [132]. However, Marsden and Chotkowski [133] suggested that zebra mussels decreased lake trout Salvelinus namaycush natural reproduction in Lake Michigan by altering reef spawning habitat and increasing the potential for egg predation.

No impacts on fish populations due to zebra mussels have been identified in South Dakota. However, zebra mussels do not have a long history in the state and specific studies focused on potential zebra mussel impacts have not been undertaken.

\section{Control}

Characteristics such as high fecundity [1] [5] [6], free swimming larvae [12] [16], and the ability to attach to a variety of surfaces [7] [8] [9] [10] make zebra mussel control extremely difficult. Once a zebra mussel population is established, chemical control is possible on smaller water bodies in closed systems [134]. However, chemical control is very expensive, limiting its use [135] [136]. A potassium solution was used to successfully eradicate zebra mussels from a 12-acre enclosed lake in Virginia [136]. Copper sulfate was used for zebra mussel control at Offutt Air Force Base Lake, Nebraska in 2008, but two years later, adult zebra mussels were again found in the lake (Tony Barada Nebraska Game and Parks, personal communication). Copper sulfate and other chemical molluscicides have the potential to negatively impact native mussel species [136] [137], as well as zooplankton, macroinvertebrates and fish species [136] [138].

Physical removal has also been used for zebra mussel control [139]. Repeated zebra mussel removals by divers in Lake George, New York [140], reduced zebra mussel populations to where reproduction and recruitment were encumbered, and further recruitment prevented [141]. However, water chemistry in Lake George was unfavorable for zebra mussel development which may have allowed for scuba removals to be successful [141]. The placement of tarps over zebra mussels to deprive them of oxygen, paired with chemical applications, has been used for mussel control in California [139].

Drawdowns are another mechanical control method. A drawdown simply in- 
volves lowering the water level to expose zebra mussels to adverse environmental conditions leading to desiccation or freezing. In Nebraska, zebra mussels were eradicated from Zorinsky and Cunningham Reservoirs using drawdowns (Tony Barada Nebraska Game and Parks, personal communication). In Zorinsky Reservoir the drawdown was followed by a chemical fish treatment.

Biological control has also been used against zebra mussel populations. A biopesticide (Zequanox, Marrone Bio Innovations, Davis, California, USA) contains a killed strain of Pseudomonas flourescens (Pf-CL145A), that when ingested damages the digestive tract of mussels causing death, with no impacts on fish, native mollusks, birds, plants, algae, and numerous invertebrates [139] [142] [143]. When used at Christmas Lake in Minnesota, zebra mussels were completely removed within the treatment area [144]. However, such treatments can be costly, at up to 11,000 USD per acre [145].

Because of the difficulty and expense of control after zebra mussel introductions, preventing the anthropogenic spread of zebra mussels has become a focus of natural resource managers in North America [146]. Considerable attention has focused on recreational watercraft inspections and disinfections [147] [148]. In addition, protocols to allow for the safe movement of fish and fish eggs between water bodies have also been developed [149] [150] [151] [152]. All of these preventative measures have been used in South Dakota.

\section{Acknowledgements}

We thank Jill Voorhees and Amy Gebhard for their assistance with this manuscript.

\section{Conflicts of Interest}

The authors declare no conflicts of interest regarding the publication of this paper.

\section{References}

[1] Malik Mackie, G.L., Gibbons, W.N., Muncaster, B.W. and Gray, I.M. (1989) The Zebra Mussel, Dreissena polymorpha: A Synthesis of European Experiences and a Preview for North America. Ontario Ministry of Environment, Ontario.

[2] Morton, B. (1993) The Anatomy of Dreissena polymorpha and the Evolution and Success of the Heteromyarian Form in the Dreissenoidea. In: Nalepa, T.F. and Schloesser, D.W., Eds., Zebra Mussels Biology, Impacts, and Control, Lewis Publishers, Boca Raton, 185-215.

[3] Strayer, D.L. (1999) Effects of Alien Species on Freshwater Molluska in North America. Journal of the North American Benthological Society, 18, 74-98. https://doi.org/10.2307/1468010

[4] Mackie, G.L. and Schloesser, D.W. (1996) Comparative Biology of Zebra Mussels in Europe and North America: An Overview. American Zoologist, 36, 244-258. https://doi.org/10.1093/icb/36.3.244

[5] Borcherding, J. (1992) Morphometric Changes in Relation to the Annual Reproductive Cycle in Dreissena polymorpha-A Prerequisite for Biomonitoring Studies with 
Zebra Mussels. Limnologie Aktuell, 4, 87-99.

[6] Marsden, J.E. (1992) Standard Protocols for Monitoring and Sampling Zebra Mussels. Illinois Natural History Survey, Champaign.

https://doi.org/10.5962/bhl.title.15187

[7] Ackerman, J.D., Ethier, C.R., Allen, D.G. and Spelt, J.K. (1993) The Biomechanics of Byssal Adhesion in Zebra Mussels (Dreissena polymoprha): Tests with a Rotating Disk. In: Nalepa, T.F. and Schloesser, D.W., Eds., Zebra Mussels Biology, Impacts, and Control, Lewis Publishers, Boca Raton, 265-282.

[8] Sprung, M. (1993) The Other Life: An Account of Present Knowledge of the Larval Phase of Dreissena polymorpha. In: Nalepa, T.F. and Schloesser, D.W., Eds., Zebra Mussels Biology, Impacts, and Control, Lewis Publishers, Boca Raton, 39-54.

[9] Marsden, J.E. and Lansky, D.M. (2000) Substrate Selection by Settling Zebra Mussels, Dreissena polymorpha, Relative to Material, Texture, Orientation, and Sunlight. Canadian Journal of Zoology, 78, 787-793. https://doi.org/10.1139/z00-004

[10] Kobak, J. (2014) Chapter 21: Behavior of Juvenile and Adult Zebra Mussels (Dreissena polymorpha). In: Nalepa, T.F. and Schloesser, D.W., Eds., Quagga and Zebra Mussels Biology, Impacts, and Control, 2nd Edition, Taylor and Francis, Boca Raton, 329-342.

[11] Haag, W.R. (2012) North American Freshwater Mussels: Natural History, Ecology and Conservation. Cambridge University Press, New York.

https://doi.org/10.1017/CBO9781139048217

[12] Sprung, M. (1989) Field and Laboratory Observations of Dreissena polymoprha Larvae: Abundance, Growth, Mortality and Food Demands. Archiv für Hydrobiologie, 115, 537-561.

[13] Pollux, B.J.A., van der Velde, G. and Bij de Vaate, A. (2010) Chapter 4: A Perspective on Global Spread of Dreissena polymorpha: A Review on Possibilities and Limitations. In: van der Velde, G. and Bij de Vaate, A., Eds., The Zebra Mussel in Europe, Backhuys Publishers, Leiden Margraf Publishers, Weikersheim, 45-58.

[14] Walz, N. (1973) Untersuchugen Zur Biologie von Dreissena polymorpha Pallas im Bodensee. Archiv für Hydrobiologie, 42, 78-85.

[15] Ackerman, J.D., Sim, B., Nichols, S.J. and Claudi, R. (1994) A Review of the Early Life History of Zebra Mussels (Dreissena polymorpha): Comparisons with Marine Bivalves. Canada Journal of Zoology, 72, 1169-1179.

https://doi.org/10.1139/z94-157

[16] Nichols, S.J. (1996) Variations in the Reproductive Cycle of Dreissena polymorpha in Europe, Russia and North America. American Zoologist, 36, 311-325. https://doi.org/10.1093/icb/36.3.311

[17] Griffiths, R.W., Schloesser, D.W., Leach, J.H. and Kovalak, W.P. (1991) Distribution and Dispersal of the Zebra Mussels (Dreissena polymorpha) in the Great Lakes Region. Canadian Journal of Fisheries and Aquatic Sciences, 48, 1381-1388. https://doi.org/10.1139/f91-165

[18] Carlton, J.T. (1993) Dispersal Mechanisms of the Zebra Mussel (Dreissena polymorpha). In: Nalepa, T.F. and Schloesser, D.W., Eds., Zebra Mussels Biology, Impacts, and Control, Lewis Publishers, Boca Raton, 677-696.

[19] Benson, A.J. (2014) Chapter 1: Chronological History of Zebra and Quagga Mussels (Dreissenidae) in North America, 1988-2010. In: Nalepa, T.F. and Schloesser, D.W., Eds., Quagga and Zebra Mussels Biology, Impacts, and Control, 5th Edition, Taylor and Francis, Boca Raton, 7-30. 
[20] McMahon, R.F. (1996) The Physiological Ecology of the Zebra Mussel, Dreissena polymorpha, in North America and Europe. American Zoologist, 36, 339-363. https://doi.org/10.1093/icb/36.3.339

[21] Bartell, S.M. and Orr, J. (2007) Risk Assessment and Decision Analysis Support for Invasive Mussel Management for the St. Croix Basin and Adjacent Upper Mississippi River. Final Report No. W912ES-05-D0002, U.S. Army Corps of Engineers, St. Paul.

[22] Kilgour, V.W. and Mackie, G.L. (1993) Colonization of Different Construction Materials by the Zebra Mussel (Dreissena polymorpha). In: Nalepa, T.F. and Schloesser, D.W., Eds., Zebra Mussels Biology, Impacts, and Control, Lewis Publishers, Boca Raton, 167-181.

[23] Stańczykowska, A. and Lewsandowski, K. (1993) Thirty Years of Studies of Dreissena polymoprha Ecology in Mazurian Lakes of Northeastern Poland. In: Nalepa, T.F. and Schloesser, D.W., Eds., Zebra Mussels Biology, Impacts, and Control, Lewis Publishers, Boca Raton, 3-33.

[24] Porter, A.E. and Marsden, J.E. (2008) Adult Zebra Mussels (Dreissena polymorpha) Avoid Attachment of Mesh Materials. Northeastern Naturalist, 15, 589-594. https://doi.org/10.1656/1092-6194-15.4.589

[25] Mackie, G.L. (1993) Biology of Zebra Mussels (Dreissena polymorpha) and Observations of Mussel Colonization on Unionid Bivalves in Lake St. Clair of the Great Lakes. In: Nalepa, T.F. and Schloesser, D.W., Eds., Zebra Mussels Biology, Impacts, and Control, Lewis Publishers, Boca Raton, 153-165.

[26] Miller, A.C., Payne, B.S., Neilsen, F. and McMahon, R.F. (1992) Zebra Mussel: Control Strategies for Zebra Mussel Infestations at Public Facilities. Technical Report EL-92-95, U.S. Army Corps of Engineers, Waterways Experiment Station, Vicksburg, Mississippi.

[27] Lewandoski, K. (1982) The Role of Early Developmental Stages in the Dynamics of Dreissena polymorpha (Pall.) (Bivalvia) Populations in Lakes II. Settling of Larvae and the Dynamics of Settled Individuals. Ekologia Polska, 30, 223-286.

[28] Kirpichenko, M.J. (1964) Phenology, Population Dynamics, and Growth of Dreissena larvae in the Kuibyshev Reservoir. In: Shtegman, B.K., Ed., Biology and Control of Dreissena, Israel Program for Scientific Translations, Jerusalem, 15-24.

[29] Toomey, M.B., McCabe, D. and Marsden, J.E. (2002) Factors Affecting the Movement of Adult Zebra Mussels (Dreissena polymoprha). Journal of the North American Benthological Society, 21, 468-475. https://doi.org/10.2307/1468483

[30] Zhang, Y., Steens Jr., S.E. and Wong, T.Y. (1998) Factors Affecting Rearing of Settled Zebra Mussels in a Controlled Flow-Through System. The Progressive Fish-Culturist, 60, 231-235. https://doi.org/10.1577/1548-8640(1998)060<0231:FAROSZ>2.0.CO;2

[31] Kobak, J. (2005) Recruitment and Distribution of Dreissena polymorpha (Bivalvia) on Substrates of Different Shape and Orientation. International Review of Hydrobiology, 90, 159-170. https://doi.org/10.1002/iroh.200410756

[32] Chase, M.E. and Bailey, R.C. (1999) The Ecology of the Zebra Mussel (Dreissena polymorpha) in the Lower Great Lakes of North America: I. Population Dynamics and Growth. Journal of Great Lakes Research, 25, 107-121. https://doi.org/10.1016/S0380-1330(99)70720-3

[33] Eckroat, L.R., Masteller, E.C., Shaffer, J.C. and Steele, L.M. (1993) The Byssus of the Zebra Mussel (Dreissena polymorpha): Morphology, Byssal Thread Formation, and Detachment. In: Nalepa, T.F. and Schloesser, D.W., Eds., Zebra Mussels Biology, Impacts, and Control, Lewis Publishers, Boca Raton, 239-263. 
[34] Martel, A. (1993) Dispersal and Recruitment and Zebra Mussel (Dreissena polymorpha) in Nearshore Area in West-Central Lake Erie: The Significance of Post-Metamorphic Drifting. Canadian Journal of Fisheries and Aquatic Sciences, 50, 3-12. https://doi.org/10.1139/f93-001

[35] Kobak, J. (2004) Recruitment and Small-Scale Spatial Distribution of Dreissena polymorpha (Bivalva) on Artificial Materials. Archiv für Hydrobiologie, 160, 25-44. https://doi.org/10.1127/0003-9136/2004/0160-0025

[36] Burks, R.L., Tuchman, N.C., Call, C.A. and Marsden, J.E. (2002) Colonial Aggregates: Effects of Spatial Position on Zebra Mussel Responses to Vertical Gradients in Interstitial Water Quality. Journal of the North American Benthological Society, 21, 64-75. https://doi.org/10.2307/1468300

[37] Tuchman, N.C., Burks, R.L., Call, C.A. and Smarrelli, J. (2004) Flow Rate and Vertical Position Influence Ingestion Rates of Colonial Zebra Mussels (Dreissena polymorpha). Freshwater Biology, 49, 191-198. https://doi.org/10.1046/j.1365-2426.2003.01176.x

[38] Stańczykowska, A. (1964) On the Relationship between Abundance, Aggregations and "Condition" of Driessena polymorpha Pall, in 36 Masurian Lakes. Ekologia Polska A, 12, 653-689.

[39] Cohen, A.N. (2007) Potential Distribution of Zebra Mussels (Dreissena polymorpha) and Quagga Mussels (Dreissena bugensis) in California. Phase 1 Report, San Francisco Estuary Institute, Oakland.

[40] Spidle, A.P., Mills, E.L. and May, B. (1995) Limits to Tolerance of Temperature and Salinity in the Quagga Mussel (Dreissena bugensis) and Zebra Mussel (Dreissena polymorpha). Canadian Journal of Fisheries and Aquatic Science, 52, 2108-2119. https://doi.org/10.1139/f95-804

[41] Elderkin, C.L. and Klerks, P.L. (2005) Variation in Thermal Tolerance among Three Mississippi River Populations of the Zebra Mussel Dreissena polymorpha. Journal of Shellfish Research, 24, 221-226. https://doi.org/10.2983/0730-8000(2005)24[221:VITTAT]2.0.CO;2

[42] Cohen, A.N. (2005) A Review of Zebra of Zebra Mussels' Environmental Requirements. San Francisco Estuary Institute, Oakland.

[43] Walz, N. (1978) The Energy Balance of the Freshwater Mussel Dreissena polymorpha Pallas in Laboratory Experiment Sand in Lake Constance. III. Growth under Standard Conditions. Archiv für Hydrobiologie, 55, 121-141.

[44] Garton, D.W. and Johnson, L.E. (2000) Variation in Growth Rates of the Zebra Mussel, Dreissena polymorpha, within Lake Wawasee. Freshwater Biology, 45, 443-451. https://doi.org/10.1046/j.1365-2427.2000.00641.x

[45] Baker, P., Baker, S. and Mann, R. (1993) Criteria for Predicting Zebra Mussel Invasions in the Mid-Atlantic Region. Marine Resource Advisory No. 50; VSG-93-04, Virginia Institute of Marine Science, William \& Mary, Gloucester Point.

[46] Neary, B.P. and Leach, J.H. (1991) Mapping the Potential Spread of the Zebra Mussel (Dreissena polymorpha) in Ontario. Canadian Journal of Fisheries and Aquatic Sciences, 49, 407-415. https://doi.org/10.1139/f92-046

[47] Hinks, S.S. and Mackie, G.L. (1997) Effects of pH, Calcium, Alkalinity, Hardness, and Chlorophyll on the Survival, Growth, and Reproduction Success of Zebra Mussel (Dreissena polymorpha) in Ontario Lakes. Canadian Journal of Fisheries and Aquatic Sciences, 54, 2029-2057. https://doi.org/10.1139/f97-114

[48] Chetail, M. and Krampitz, G. (1982) Calcium and Skeletal Structures in Molluscs: Concluding Remarks. Malacologia, 22, 337-339. 
[49] Garton, D.W., McMahon, R. and Stoeckmann, A.M. (2014) Chapter 25: Limiting Environmental Factors and Competitive Interactions between Zebra and Quagga Mussels in North America. In: Nalepa, T.F. and Schloesser, D.W., Eds., Quagga and Zebra Mussels Biology, Impacts, and Control, 2nd Edition, Taylor and Francis, Boca Raton, 381-400. https://doi.org/10.1201/b15437-32

[50] Mihuc, T.B., Battle, J.M., Mihuc, J.R. and Bryan, C.F. (1999) Zebra Mussel (Dreissena polymorpha) Seasonal Colonization Patterns in a Sub-Tropical Floodplain River. Hydrobiologia, 392, 121-128. https://doi.org/10.1023/A:1003586524471

[51] Madon, S.P., Schneider, D.W., Stoeckel, J.A. and Sparks, R.E. (1998) Effects of Inorganic Sediments on Energetic Processes of the Zebra Mussel, Dreissena polymorpha: Implications for Growth in Turbid Rivers. Canadian Journal of Fisheries and Aquatic Sciences, 55, 401-413. https://doi.org/10.1139/f97-214

[52] Strayer, D.L. and Smith, L. (1993) Distribution of Zebra Mussels (Dreissena polymorpha) in Estuaries and Brackish Waters. In: Nalepa, T.F. and Schloesser, D.W., Eds., Zebra Mussels Biology, Impacts, and Control, Lewis Publishers, Boca Raton, 715-727.

[53] Mills, E.L., Rosenberg, G., Spidle, A.P., Ludyanskiy, M., Pligin, Y. and May, B. (1996) A Review of the Biology and Ecology of Quagga Mussel (Dreissena bugensis), a Second Species of Freshwater Dreissenid Introduced into North America. American Zoologist, 36, 271-286. https://doi.org/10.1093/icb/36.3.271

[54] Lei, J., Payne, B.S. and Wang, S.Y. (1995) Filtration Dynamics of Zebra Mussel, Dreissena polymorpha. Canadian Journal of Fisheries and Aquatic Sciences, 53, 29-37. https://doi.org/10.1139/f95-164

[55] Horgan, J.M. and Mills, E.L. (1997) Clearance Rates and Filtering Activity of Zebra Mussel (Dreissena polymorpha): Implications for Freshwater Lakes. Canadian Journal of Fisheries and Aquatic Sciences, 54, 249-255. https://doi.org/10.1139/f96-276

[56] Ten Winkel, E.H. and Davids, C. (1982) Food Selection by Dreissena polymorpha Pallas (Molluska: Bivalvia). Freshwater Biology, 12, 553-558. https://doi.org/10.1111/j.1365-2427.1982.tb00647.x

[57] Berg, D.J., Fisher, S.W. and Landrum, P.F. (1996) Clearance and Processing of Algal Particles by Zebra Mussels (Dreissena polymorpha). Journal of Great Lakes Research, 22, 779-788. https://doi.org/10.1016/S0380-1330(96)70996-6

[58] Morton, B.S. (1969) Studies on the Biology of Dreissena polymorpha Pallas. I. General Anatomy and Morphology. Proceedings of the Malacological Society of London, 38, 301-321.

[59] Hebert, P.D., Muncaster, B.W. and Mackie, G.L. (1989) Ecological and Genetic Studies of Dressena polymorpha (Pallas): A New Mollusk in the Great Lakes. Canadian Journal of Fisheries and Aquatic Sciences, 46, 1587-1591.

https://doi.org/10.1139/f89-202

[60] Garton, D.W. and Haag, W.R. (1993) Seasonal Reproductive Cycles and Settlement Patterns of Dreissena polymorpha in Western Lake Erie. In: Nalepa, T.F. and Schloesser, D.W., Eds., Zebra Mussels Biology, Impacts, and Control, Lewis Publishers, Boca Raton, 111-128.

[61] Leach, J.H. (1993) Impacts of Zebra Mussel (Dreissena polymorpha) on Water Quality and Fish Spawning Reefs in Western Lake Erie. In: Nalepa, T.F. and Schloesser, D.W., Eds., Zebra Mussels Biology, Impacts, and Control, Lewis Publishers, Boca Raton, 381-398.

[62] Cope, W.G., Bartsch, M.R. and Hayden, R.R. (1997) Longitudinal Patters in Abun- 
dance of the Zebra Mussel (Dreissena polymorpha) in the Upper Mississippi River. Journal of Freshwater Ecology, 12, 235-238. https://doi.org/10.1080/02705060.1997.9663531

[63] Benson, A.J., Raikow, D., Larson, J., Fusaro, A, Bogdanoff, A.K. and Elgin, A. (2019) Dreissena polymorpha (Pallas, 1771): U.S. Geological Survey, Nonindigenous Aquatic Species Database. Gainesville.

[64] Wollman, K. (2019) Assessing Freshwater Mussel (Bibalvia: Unionidae) Assemblages and Effects of Eutrophication on Pygandon grandis in Lakes of Eastern South Dakota. Master's Thesis, South Dakota State University, Brookings.

[65] Johnson, L.E. and Padilla, D.K. (1996) Geographic Spread of Exotic Species: Ecological Lessons and Opportunities from the Invasion of the Zebra Mussel Dreissena polymorpha. Biological Conservation, 78, 23-33.

https://doi.org/10.1016/0006-3207(96)00015-8

[66] Johnson, L.E., Ricciardi, A. and Carlton, J.T. (2001) Overland Dispersal of Aquatic Invasive Species: A Risk Assessment of Transient Recreational Boating. Ecological Applications, 11, 17989-1799.

https://doi.org/10.1890/1051-0761(2001)011[1789:ODOAIS]2.0.CO;2

[67] Claudi, R. and Mackie, G.L. (1993) Practical Manual for Zebra Mussel Monitoring and Control. Lewis Publishers, Boca Raton.

[68] Ricciardi, A., Serrouya, R. and Whoriskey, F.G. (1994) Aerial Exposure Tolerance of Zebra and Quagga Mussels (Bivalvia: Dreissenidae): Implications for Overland Dispersal. Canadian Journal of Fisheries and Aquatic Sciences, 52, 470-477. https://doi.org/10.1139/f95-048

[69] Tucker, J.K., Theiling, C.H., Janzen, F.J. and Paukstis, G.L. (1997) Sensitivity to Aerial Exposure: Potential of System-Wide Drawdowns to Manage Zebra Mussels in the Mississippi River. Regulated Rivers. Research \& Management, 13, 479-487. https://doi.org/10.1002/(SICI)1099-1646(199711/12)13:6<479::AID-RRR469>3.0.C $\underline{\mathrm{O} ; 2-\mathrm{B}}$

[70] Johnson, L.E. and Carlton, J.T. (1996) Post-Establishment Spread in Large-Scale Invasions: Dispersal Mechanisms of the Zebra Mussel Dreissena polymorpha. Ecolo$g y, 77,1686-1690$. https://doi.org/10.2307/2265774

[71] Banha, F., Gimeno, I., Lanao, M., Touya, V., Durán, C., Perlbáñez, M.A. and Anastácio, P.M. (2016) The Role of Waterfowl and Fishing Gear on Zebra Mussel Larvae Dispersal. Biological Invasions, 18, 115-125. https://doi.org/10.1007/s10530-015-0995-Z

[72] Johnson, L.E. and Carlton, J.T. (1992) Counter-Productive Public Policy: The "Noah Fallacy" and Other Mussel Myths. Dreissena polymorpha Information Review, 3, 2-4.

[73] Morton, B., Velkovrh, F. and Sket, B. (1998) Biology and Anatomy of the "Living Fossil" Congeria kusceri (Bivalvia: Dreissenidae) from Subterranean Rivers and Caves in the Dinaric Karst of the former Yugoslavia. Journal of Zoology, 245, 147-174.

[74] Padilla, D.K., Chotkowski, M.A. and Buchan, L.A.J. (1996) Predicting the Spread of Zebra Mussels (Dreissena polymorpha) to Inland Watersheds: Consequences of Boater Movement Patterns. Global Ecology and Biogeography Letters, 5, 353-359. https://doi.org/10.2307/2997590

[75] Haag, W.R., Berg, D.J., Garton, D.W. and Farris, J.L. (1993) Reduced Survival and Fitness in Native Bivalves in Response to Fouling by the Introduced Zebra Mussel (Dreissena polymorpha) in Western Lake Erie. Canadian Journal of Fisheries and 
Aquatic Sciences, 50, 13-19. https://doi.org/10.1139/f93-002

[76] MacIsaac, H.J. (1996) Potential Abiotic and Biotic Impacts of Zebra Mussels on the Inland Waters of North America. American Zoologist, 36, 287-299.

https://doi.org/10.1093/icb/36.3.287

[77] Pace, M.L., Findlay, S.E.G. and Fischer, D. (1998) Effects of an Invasive Bivalve on the Zooplankton Community of the Hudson River. Freshwater Biology, 39, 103-116. https://doi.org/10.1046/j.1365-2427.1998.00266.x

[78] Jack, D.J. and Thorp, J.H. (2000) Effects of the Benthic Suspension Feeder Dreissena polymorpha on Zooplankton in a Large River. Freshwater Biology, 44, 569-579. https://doi.org/10.1046/j.1365-2427.2000.00609.x

[79] Zhu, B., Fitzgerald, D.G., Mayer, C.M., Rudstam, L.G. and Mills, E.L. (2006) Alteration of Ecosystem Function by Zebra Mussels in Oneida Lake: Impacts on Submerged Macrophytes. Ecosystems, 9, 1017-1028. https://doi.org/10.1007/s10021-005-0049-y

[80] Ward, J.M. and Ricciardi, A. (2007) Impacts of Dreissena Invasions on Benthic Macroinvertebrate Communities: A Meta-Analysis. Diversity and Distributions, 13 , 155-165. https://doi.org/10.1111/j.1472-4642.2007.00336.x

[81] Higgins, R.M., Grennan, J.M. and McCarthy, K.T. (2008) Effects of Recent Zebra Mussel Invasion on Water Chemistry and Phytoplankton Production in a Small Irish Lake. Aquatic Invasions, 3, 14-20. https://doi.org/10.3391/ai.2008.3.1.4

[82] Vanderploeg, H.A., Nalepa, T.F., Jude, D.J., Mills, E.L., Holeck, K.T., Liebig, J.R., Grigorovich, I.A. and Ojaveer, H. (2002) Dispersal and Emerging Ecological Impacts of Ponto-Caspian Species in the Laurentian Great Lakes. Canadian Journal of Fisheries and Aquatic Sciences, 59, 1209-1228. https://doi.org/10.1139/f02-087

[83] Barbiero, R.P. and Tuchman, M.L. (2004) Long-Term Dreissenid Impacts on Water Clarity in Lake Erie. Journal of Great Lakes Research, 30, 557-565.

https://doi.org/10.1016/S0380-1330(04)70371-8

[84] De Stasio, B.T., Schrimpf, M.B., Beranek, A.E. and Daniels, W.C. (2008) Increased Chlorophyll a, Phytoplankton Abundance, and Cyanobacteria Occurrence Following Invasion of Green Bay, Lake Michigan by Dreissenid Mussels. Aquatic Invasions, 3, 21-27. https://doi.org/10.3391/ai.2008.3.1.5

[85] Griffiths, R.W. (1993) Effects of Zebra Mussels (Dreissena polymorpha) on the Benthic Fauna of Lake St. Clair. In: Nalepa, T.F. and Schloesser, D.W., Eds., Zebra Mussels Biology, Impacts, and Control, Lewis Publishers, Boca Raton, 415-437.

[86] Yu, N. and Culver, D.A. (2000) Can Zebra Mussels Change Stratification Patterns in a Small Reservoir? Hydrobiologia, 431, 175-184.

https://doi.org/10.1023/A:1004092229180

[87] Lavrentyev, P.J., Gardner, W.S., Cavaletto, J.F. and Beaver, J.R. (1995) Effects of the Zebra Mussel (Dreissena polymorpha Pallas) on Protozoa and Phytoplankton from Saginaw Bay, Lake Huron. Journal of Great Lakes Research, 21, 545-557. https://doi.org/10.1016/S0380-1330(95)71065-6

[88] Idrisi, N., Mills, E.L., Rudstam, L.G. and Stewart, D.J. (2001) Impact of Zebra Mussels (Dreissena polymorpha) on the Pelagic Lower Trophic Levels on Oneida Lake, New York. Canadian Journal of Fisheries and Aquatic Sciences, 58, 1430-1441. https://doi.org/10.1139/f01-070

[89] Raikow, D.F., Sarnelle, O., Wilson, A.E. and Hamilton, S.K. (2004) Dominance of the Noxious Cyanobacterium Microcystis aeruginosa in Low-Nutrient Lakes Is Associated with Exotic Zebra Mussels. Limnology and Oceanography, 49, 482-487. 
https://doi.org/10.4319/lo.2004.49.2.0482

[90] Barbiero, R.P., Rockwell, D.C., Warren, G.J. and Tuchman, M.L. (2006) Changes in Spring Phytoplankton Communities and Nutrient Dynamics in the Eastern Basin of Lake Erie since the Invasion of Dreissena spp. Canadian Journal of Fisheries and Aquatic Sciences, 63, 1549-1563. https://doi.org/10.1139/f06-059

[91] Depew, D.C., Guildford, S.J. and Smith, R.E.H. (2006) Nearshore-Offshore Comparison of Chlorophyll $a$ and Phytoplankton Production in the Dreissenid-Colonized Eastern Basin of Lake Erie. Canadian Journal of Fisheries and Aquatic Sciences, 63, 1115-1129. https://doi.org/10.1139/f06-016

[92] Wilson, A.E. (2003) Effects of Zebra Mussels on Phytoplankton and Ciliates: A Field Mesocosm Experiment. Journal of Plankton Research, 25, 905-915. https://doi.org/10.1093/plankt/25.8.905

[93] Naddafi, R., Pettersson, K. and Eklöv, P. (2007) The Effect of Seasonal Variation in Selective Feeding by Zebra Mussels (Dreissena polymorpha) on Phytoplankton Community Composition. Freshwater Biology, 52, 823-842.

https://doi.org/10.1111/j.1365-2427.2007.01732.x

[94] Vanderploeg, H.A., Liebig, J.R., Carmichael, W.W., Agy, M.A., Johengen, T.H., Fahnestiel, G.L. and Nalepa, T.F. (2001) Zebra Mussels (Dreissena polymorpha) Selective Filtration Promoted Toxic Microcystis Blooms in Saginw Bay (Lake Huron) and Lake Erie. Canadian Journal of Fisheries and Aquatic Science, 58, 1208-1221. https://doi.org/10.1139/f01-066

[95] Sarnelle, O., Wilson, A.E., Hamilton, S.K., Knoll, L.B. and Raikow, D.F. (2005) Complex Interactions between the Zebra Mussel, Dreissena polymorpha, and the Harmful Phytoplankter, Microcystis aeruginosa. Limnology and Oceanography, 50, 896-904. https://doi.org/10.4319/lo.2005.50.3.0896

[96] Bykova, O., Laursen, A., Bostan, V., Bausista, J. and McCarthy, L. (2006) Do Zebra Mussels (Dreissena polymorpha) Alter Lake Water Chemistry in a Way That Favors Microsystis Growth? Science of the Total Environment, 371, 362-372. https://doi.org/10.1016/j.scitotenv.2006.08.022

[97] Knoll, L.B., Sarnelle, O., Hamilton, S.K., Kissman, C.E.H., Wilson, A.E., Rose, J.B. and Morgan, M.R. (2008) Invasive Zebra Mussels (Dreissena polymorpha) Increase Cyanobacterial Toxin Concentrations in Low-Nutrient Lakes. Canadian Journal of Fisheries and Aquatic Sciences, 65, 448-455. https://doi.org/10.1139/f07-181

[98] Carmichael, W.W. (1996) Chapter 1: Toxic Microcystis and the Environment. In: Watanabe, M.F. and Fujiki, H., Eds., Toxic Microcystis, CRC Press, Boca Raton, $1-11$.

[99] Thorp, J.H. and Casper, A.F. (2002) Potential Effects of Zooplankton from Species Shifts in Planktivorous Mussels: A Field Experiment in the St. Lawrence River. Freshwater Biology, 47, 107-119. https://doi.org/10.1046/j.1365-2427.2002.00787.x

[100] MacIsaac, H.J., Sprules, W.G. and Leach, J.H. (1991) Ingestion of Small-Bodied Zooplankton by Zebra Mussels (Dreissena polymorpha): Can Cannibalism on Larvae Influence Population Dynamics? Canadian Journal of Fisheries and Aquatic Sciences, 47, 2051-2060. https://doi.org/10.1139/f91-244

[101] Richardson, W.B. and Bartsch, L.A. (1997) Effects of Zebra Mussels on Food Webs: Interactions with Juvenile Bluegill and Water Residence Time. Hydrobiologia, 354, 141-150. https://doi.org/10.1023/A:1003048431234

[102] David, K.A., Davis, B.M. and Hunter, R.D. (2009) Lake St. Clair Zooplankton: Evidence for Post-Dreissena Changes. Journal of Freshwater Ecology, 24, 199-209. https://doi.org/10.1080/02705060.2009.9664284 
[103] Wu, L. and Culver, D.A. (1991) Zooplankton Grazing and Phytoplankton Abundance: An Assessment before and after Invasion of Dreissena polymorpha. Journal of Great Lakes Research, 17, 425-436. https://doi.org/10.1016/S0380-1330(91)71378-6

[104] Botts, P.S., Patterson, B.A. and Schloesser, D.W. (1996) Zebra Mussel Effects on Benthic Invertebrates: Physical or Biotic? Journal of the North American Benthological Society, 15, 179-184. https://doi.org/10.2307/1467947

[105] Ricciardi, A., Whoriskey, G.G and Rasmussen, J.B. (1997) The Role of the Zebra Mussel (Dreissena polymorpha) in Structuring Macroinvertebrate Communities on Hard Substrata. Canadian Journal of Fisheries and Aquatic Sciences, 54, 2596-2608. https://doi.org/10.1139/f97-174

[106] Steward, T.W., Miner, J.G. and Lowe, R.L. (1998) Quantifying Mechanisms for Zebra Mussel Effects on Benthic Macroinvertebrates: Organic Matter Production and Shell-Generated Habitat. Journal of the North American Benthological Society, 17, 81-94. https://doi.org/10.2307/1468053

[107] Steward, T.W., Gafford, J.C., Miner, J.G. and Lowe, R.L. (1999) Dreissena-Shell Habitat and Antipredator Behavior: Combined Effects on Survivorship of Snails Co-Occurring with Molluscivorous Fish. Journal of the North American Benthological Society, 18, 274-283. https://doi.org/10.2307/1468465

[108] González, M.J. and Downing, A. (1999) Mechanisms Underlying Amphipod Responses to Zebra Mussel (Dreissena polymorpha) Invasion and Implications for Fish-Amphipod Interactions. Canadian Journal of Fisheries and Aquatic Sciences, 56, 679-685. https://doi.org/10.1139/f98-211

[109] Mayer, C.M., Keats, R.A., Rustram, L.G. and Mills, E.L. (2002) Scale-Dependent Effects of Zebra Mussels on Benthic Invertebrates in a Large Eutrophic Lake. Journal of the North American Benthological Society, 21, 616-633. https://doi.org/10.2307/1468434

[110] Beekey, M.A., McCabe, D.J. and Marsden, J.E. (2004) Zebra Mussel Affect Benthic Predator Foraging Success and Habitat Choice on Soft Sediments. Oecolgia, 141, 164-170. https://doi.org/10.1007/s00442-004-1632-1

[111] Izvekova, E.I. and Lvova-Katchanova, A.A. (1972) Sedimentation of Suspended Matter by Dreissena polymorpha Pallas and Its Subsequent Utilization by Chrinomidae Larvae. Polskie Archiwum Hydrobiologii, 19, 203-210.

[112] Klerks, P.L., Fraleigh, P.C. and Lawniczak, J.E. (1996) Effects of Zebra Mussels (Dreissena polymorpha) on Seston Levels and Sediment Deposition in Western Lake Erie. Canadian Journal of Fisheries and Aquatic Sciences, 53, 2284-2291. https://doi.org/10.1139/f96-190

[113] Roditi, H.A., Strayer, D.L. and Findlay, S.E.G. (1997) Characteristics of Zebra Mussel (Dreissena polymorpha) Biodeposits in a Tidal Freshwater Estuary. Archiv für Hydrobiologie, 140, 207-219.

https://doi.org/10.1127/archiv-hydrobiol/140/1997/207

[114] Horvath, T.G., Martin, K.M. and Lamberti, G.A. (1999) Effects of Zebra Mussels, Dreissena polymorpha, on Macroinvertebrates in a Lake-Outlet Stream. The American Midland Naturalist, 142, 340-347. https://doi.org/10.1674/0003-0031(1999)142[0340:EOZMDP]2.0.CO;2

[115] Reed, T., Wielgus, S.J., Barnes, A.K., Schiefelbein, J.J. and Fettes, A.L. (2004) Refugia and Local Controls: Benthic Invertebrate Dynamics in Lower Green Bay, Lake Michigan Following Zebra Mussel Invasion. Journal of Great Lakes Research, 30, 390-396. https://doi.org/10.1016/S0380-1330(04)70356-1 
[116] Bially, A. and Macisaac, H.J. (2000) Fouling Mussels (Dreissena spp.) Colonize Soft Sediments in Lake Erie and Facilitate Benthic Invertebrates. Freshwater Biology, 43, 85-97. https://doi.org/10.1046/j.1365-2427.2000.00526.x

[117] Gopalan, G., Culver, D.A., Wu, L. and Trauben, B.K. (1998) Effects of Recent Ecosystem Changes on the Recruitment of Young-of-the-Year Fish in Western Lake Erie. Canadian Journal of Fisheries and Aquatic Sciences, 55, 2572-2579. https://doi.org/10.1139/f98-130

[118] Trometer, E.S. and Busch, W.D.N. (1999) Changes in Age-0 Fish Growth and Abundance Following the Introduction of Zebra Mussels Dreissena polymorpha in the Western Basin of Lake Erie. North American Journal of Fisheries Management, 19, 604-609. https://doi.org/10.1577/1548-8675(1999)019<0604:CIAFGA>2.0.CO;2

[119] Ali, M.A., Ryder, R.A. and Anctil, M. (1977) Photoreceptors and Visual Pigments as Related to Behavioral Responses and Preferred Habitat of Perches (Perca spp.) and Pikeperches (Stizostedion spp.). Journal of the Fisheries Research Board of Canada, 34, 1475-1480. https://doi.org/10.1139/f77-212

[120] Lester, N.P., Dextrase, A.J., Kushineriuk, R.S., Rawson, M.R. and Ryan, P.A. (2004) Light and Temperature: Key Factors Affecting Walleye Abundance and Production. Transactions of the American Fisheries Society, 133, 588-605. https://doi.org/10.1577/T02-111.1

[121] Skubinna, J.P. (1994) The Response of Submersed Macrophytes to Increased Water Clarity During the Establishment of Zebra Mussels, Dreissena polymorpha Pallas, in Saginaw Bay, Lake Huron. Master's Thesis, Michigan State University, East Lancing.

[122] Molloy, D.P., Karatayev, A.Y., Burlakova, L.E., Kurandina, D.P. and Laruelle, F. (1997) Natural Enemies of Zebra Mussels: Predators, Parasites, and Ecological Competitors. Reviews in Fisheries Science, 5, 27-97. https://doi.org/10.1080/10641269709388593

[123] Naddafi, R. and Rudstam, L.G. (2014) Predation on Invasive Zebra Mussel, Dreissena polymorpha, and Pumpkinseed Sunfish, Rusty Crayfish, and Round Goby. Hydrobiologia, 721, 107-115. https://doi.org/10.1007/s10750-013-1653-z

[124] Mills, E.L., O'Gorman, R., Roseman, E.F., Adams, C. and Owens, R.W. (1995) Planktivory by Alewife (Alosa pseudoharengus) and Rainbow Smelt (Osmerus mordax) on Microcrustacean Zooplankton and Dreissenid (Bivalvia:Dreissenidae) Veligers in Southern Lake Ontario. Canadian Journal of Fisheries and Aquatic Sciences, 52, 925-935. https://doi.org/10.1139/f95-092

[125] Marsden, J.E. (1997) Common Carp Diet Includes Zebra Mussels and Lake Trout Eggs. Journal of Freshwater Ecology, 12, 491-492.

https://doi.org/10.1080/02705060.1997.9663559

[126] Morrison, T.W., Lynch Jr., W.E. and Dabrowski, K. (1997) Predation on Zebra Mussels by Freshwater Drum and Yellow Perch in Western Lake Erie. Journal of Great Lakes Research, 23, 177-189. https://doi.org/10.1016/S0380-1330(97)70895-5

[127] Magoulick, D.D. and Lewis, L.C. (2002) Predation on Exotic Zebra Mussels by Native Fishes: Effects on Predator and Prey. Freshwater Biology, 47, 1908-1918. https://doi.org/10.1046/j.1365-2427.2002.00940.x

[128] Eggleton, M.A., Miranda, L.E. and Kirk, J.P. (2004) Assessing the Potential for Fish Predation to Impact Zebra Mussels (Dreissena polymorpha): Insight from Bioenergetics Models. Ecology of Freshwater Fish, 13, 85-95. https://doi.org/10.1111/j.1600-0633.2004.00033.x

[129] Gatlin, M.R., Shoup, D.E. and Long, J.M. (2013) Invasive Zebra Mussels (Dreissena polymorpha) Survive Gut Passage of Migratory Fish Species: Implications for Dis- 
persal. Biological Invasions, 15, 1195-1200.

https://doi.org/10.1007/s10530-012-0372-0

[130] Thayer, S.A., Haas, R.C., Hunter, R.D. and Kushler, R.H. (1997) Zebra Mussel (Dreissena polymorpha) Effects on Sediment, other Zoobenthos, and the Diet and Growth of Yellow Perch (Perca flavescens) in Pond Enclosures. Canadian Journal of Fisheries and Aquatic Sciences, 54, 1903-1915. https://doi.org/10.1139/f97-101

[131] Mayer, C.M., Rudstam, L.G., Mills, E.L., Cardiff, S.G. and Bloom, C.A. (2001) Zebra Mussels (Dreissena polymorpha), Habitat Alteration, and Yellow Perch (Perca flavescens) Foraging: System-Wide Effects and Behavioural Mechanisms. Canadian Journal of Fisheries and Aquatic Sciences, 58, 2459-2467. https://doi.org/10.1139/f01-176

[132] Fitzsimons, J.D., Leach, J.H., Nepszy, S.J. and Cairns, V.W. (1995) Impacts of Zebra Mussel on Walleye (Stizostedion vitreum) Reproduction in Western Lake Erie. Canadian Journal of Fisheries and Aquatic Sciences, 52, 578-586.

https://doi.org/10.1139/f95-058

[133] Marsden, J.E. and Chotkowski, M.A. (2001) Lake Trout Spawning on Artificial Reefs and the Effect of Zebra Mussels: Fatal Attraction? Journal of Great Lakes Research, 27, 33-43. https://doi.org/10.1016/S0380-1330(01)70621-1

[134] Galil, B.S. (2009) Control and Eradication of Invasive Aquatic Invertebrates. In: Gherardi, F., Corti, C. and Gaultieri, M., Eds., Biodiversity Conservation and Habitat Management, Volume II, Eolss Publishers, Oxford, 331-344.

[135] Helfrich, L.A. and Hipkins, P. (2009) Pesticides and Aquatic Animals: A Guide to Reducing Impacts on Aquatic Systems. Virginia Polytechnic and State University, Petersburg.

[136] Fernald, R.T. and Watson, B.R. (2014) Eradication of Zebra Mussels (Dreissena polymorpha) from Millbrook Quarry, Virgina: Rapid Response in the Real World. In: Nalepa, T.F. and Schloesser, D.W., Eds., Quagga and Zebra Mussels Biology, Impacts, and Control, 2nd Edition, Taylor and Francis, Boca Raton, 195-213.

[137] Mackie, G.L. and Claudi, R. (2010) Monitoring and Control of Macrofouling Mollusks in Fresh Water Systems. 2nd Edition, Taylor \& Francis Group, Boca Raton. https://doi.org/10.1201/9781439804414

[138] Bettoli, P.W. and Maceina, M.J. (1996) Sampling with Toxicants. In: Murphy, B.R. and Willis, D.W., Eds., Fisheries Techniques, 2nd Edition, American Fisheries Society, Bethesda, 303-333.

[139] Culver, C., Lahr, H., Johnson, L. and Cassel, J. (2013) Quagga and Zebra Mussel Eradiation and Control Tactics. California Sea Grant Report No. T-076 and UCCE-SD Technical Report No. 2013-1, Oakland.

[140] Sutherland, J.W., Bloomfield, J.A. and Swart, J.M. (1983) Lake George Urban Runoff Study Nationwide Urban Runoff Program. Final Report, New York State Department of Environmental Conservation, Albany.

[141] Wimbush, J., Frischer, M.E., Zarzynski, J.W. and Nierzwicki, S.A. (2009) Eradication of Colonizing Populations of Zebra Mussels (Dreissena polymorpha) by Early Detection and SCUBA Removal: Lake George, NY. Aquatic Conservation: Marine and Freshwater Ecosystems, 19, 703-713. https://doi.org/10.1002/aqc.1052

[142] Molloy, D.P., Mayer, D.A., Gaylo, M.J., Burlakova, L.E., Karatyev, A.Y., Presti, K.T., Sawyko, P.M., Morse, J.T. and Paul, E.A. (2013) Non-Target Trials with Pseudomonas fluorescens Strain CL145A, a Lethal Control Agent of Dreissenid Mussels (Bivalvia: Dreissenidae). Management of Biological Invasions, 4, 71-79.

https://doi.org/10.3391/mbi.2013.4.1.09 
[143] Pletta, M.E. (2013) Particle Capture by Freshwater Bivalves: Implications for Feedings Ecology and Biocide Delivery. Master's Thesis, Missouri State University, Springfield.

[144] Lund, K., Cattoor, K.B., Fieldseth, E., Sweet, J. and McCartney, M.A. (2018) Zebra Mussel (Dreissena polymorpha) Eradication Efforts in Christmas Lake, Minnesota. Lake and Reservoir Management, 34, 7-20. https://doi.org/10.1080/10402381.2017.1360417

[145] Adams, D.C. and Lee, D.J. (2012) Technology Adoption and Mitigation of Invasive Species Damage and Risk: Application to Zebra Mussels. Journal of Bioeconomics, 14, 21-40. https://doi.org/10.1007/s10818-011-9117-x

[146] Zook, B. and Phillips, S. (2015) Uniform Minimum Protocols and Standards for Watercraft Inspection Programs for Dreissenid Mussels in the Western United States (UMPS). In: Wong, W.H. and Gerstenberger, S.L., Eds., Biology and Management of Invasive Quagga and Zebra Mussels in the Western United States, CRC Press, Boca Raton, 175-202.

[147] Morse, J.T. (2009) Assessing the Effects of Application Time and Temperature on the Efficacy of Hot-Water Sprays to Mitigate Fouling by Dreissena polymorpha (Zebra Mussels, Pallas). Biofouling, 25, 605-610. https://doi.org/10.1080/08927010902989245

[148] Rothlisberger, J.D., Chadderton, W.L., McNulty, J. and Lodge, D.M. (2010) Aquatic Invasive Species Transport via Trailered Boats: What Is Being Moved, Who Is Moving It, and What Can Be Done. Fisheries, 35, 121-132. https://doi.org/10.1577/1548-8446-35.3.121

[149] Edwards, W.J., Babcock-Jackson, L. and Culver, D.A. (2000) Prevention of the Spread of Zebra Mussels during Fish Hatchery and Aquaculture Activities. North American Journal of Aquaculture, 62, 229-236. https://doi.org/10.1577/1548-8454(2000)062<0229:POTSOZ>2.3.CO;2

[150] Edwards, W.J., Babcock-Jackson, L. and Culver, D.A. (2002) Field Testing of Protocols to Prevent the Spread of Zebra Mussels (Dreissena polymorpha) during Fish Hatchery and Aquaculture Activities. North American Journal of Aquaculture, 64, 220-223. https://doi.org/10.1577/1548-8454(2002)064<0220:FTOPTP >2.0.CO;2

[151] Crank, K.M. and Barnes, M.E. (2017) Zebra Mussel Veliger Chemical Control Treatments Do Not Impact Rainbow Trout Eyed Egg Survival. International Journal of Innovative Studies in Aquatic Biology and Fisheries, 3, 15-17.

https://doi.org/10.20431/2454-7670.0302003

[152] Hillard, S., Huysman, N. and Barnes, M.E. (2019) Impact of Zebra Mussel Veliger Control Treatments on the Survival of Water-Hardened Landlocked Fall Chinook Salmon Eggs. Natural Resources, 10, 115-120.

https://doi.org/10.4236/nr.2019.104008 